\title{
SLOVENSKÉ A POLSKÉ LINGVISTICKÉ TERMÍNY MORFOLOGICKEJ ROVINY Z ASPEKTU VYBRANÝCH TYPOV LEXIKÁLNEJ MOTIVÁCIE
}

\author{
Slovak and Polish Linguistic Terms of Morphology in the View \\ of Selected Lexical Motivation Types
}

Keywords: Slovak language, Polish language, linguistic terms, lexikal motivation

Contact: Prešovská univerzita v Prešove; dominika.vincejova@smail.unipo.sk

\section{0 Úvod}

Jazykovedná terminológia je základným pilierom lingvistiky a odráža súčasný stav spracovania vedeckých poznatkov, metód a smerov lingvistického výskumu v danom jazyku, ako aj vo svetovej jazykovede. Lingvistickú terminológiu tvorí súbor pomenovaní jednotlivých javov v oblasti lingvistiky a zohráva významnú úlohu pri štúdiu materinského či cudzieho jazyka.

Ciel'om našej komparatívnej práce je poukázat' na zhody, ale aj rozdiely medzi terminologickými jednotkami morfologickej roviny porovnávaných jazykových systémov slovenčiny a pol’štiny. V prekladanej práci sa zameriame na dva typy lexikálnej motivácie - interlingválnu motiváciu a abreviačnú motiváciu. Interlingválne motivácia predstavuje lexikálnej jednotky, ktoré boli prevzaté z cudzích jazykov a tvoria početnú zložku v lexikálnej zásobe slovenčiny a pol’štiny, nevynímajúc jazykovednú terminológiu, v ktorej interlingválne motivované termíny (prevzaté termíny) kvantitatívne prevažujú nad interlingválne nemotivovanými termínmi (termíny domáceho pôvodu). Abreviačná motivácia predstavuje abreviačne motivované jednotky, t. j. skratky, ktoré si v posledných desat'ročiach našli svoje významné uplatnenie nielen v spoločenskom živote, ale aj jazykovedná terminologická sústava slovenčiny a pol'štiny si čoraz častejšie osvojuje skracovanie lingvistických termínov (najmä $\mathrm{v}$ písomnej podobe). Vychádzat' budeme $\mathrm{z}$ teórie lexikálnej motivácie, z prvotnej typológie lexikálnej motivácie a pojmovo-terminologického vymedzenia jednotlivých motivačných typov J. Furdíka (2008), a viacerých prác M. Ološtiaka, ktorý teóriu lexikálnej motivácie rozvinul. 


\section{Morfologické termíny $\mathrm{z}$ aspektu interlingválnej motivácie}

Rovnako ako v terminológii iných odborov vedy a techniky (napr. medicína, botanika, informatika), aj v jazykovednej terminológii sa stretávame s vel'kým množstvom lexém prevzatých z cudzích jazykov. Takéto lexémy sa nazývajú interlingválne motivované a tvoria početnú zložku nielen $\mathrm{v}$ odbornej terminológii, ale aj v lexikálnej zásobe ako celku. Preberanie lexém je v posledných desat'ročiach jedným z najproduktívnejších spôsobov obohacovania lexiky, vrátane lingvistickej terminológie, v ktorej prevzaté termíny kvantitatívne prevažujú nad domácimi termínmi. Z tohto dôvodu sme sa rozhodli venovat' pozornost' práve týmto interlingválne motivovaným lexémam v slovenskej a pol'skej jazykovednej terminológii, ktoré opíšeme a porovnáme na základe interlingválnej motivácie, ktorá je jedným z typov lexikálnej motivácie. Ciel’om nášho príspevku je zistit', $\mathrm{z}$ akých jazykov boli prevzaté lingvistické termíny $\mathrm{v}$ slovenčine a pol'štine $\mathrm{v}$ rámci morfologickej roviny a percentuálne ich vyčíslit' analýzou lexikografického spracovania slovenskej a pol'skej jazykovednej terminológie. Prostredníctvom našej analýzy opíšeme a porovnáme slovenské a pol'ské lingvistické termíny ako interlingválne motivované jednotky; zdôrazníme medzijazykové diferencie a upozorníme na zhody. Budeme vychádzat' z prvotnej typológie lexikálnej motivácie a pojmovo-terminologického vymedzenia jednotlivých motivačných typov J. Furdíka (2008), a viacerých prác M. Ološtiaka (porov. d’alej), ktorý túto teóriu rozvinul.

V našej štúdii vychádzame z teórie lexikálnej motivácie, ktorá vznikla v slovenskom lingvistickom prostredí. Ide o jedinečnú koncepciu slovenského jazykovedca Juraja Furdíka (2008), ktorá predstavuje jeden z možných celkových prístupov k skúmaniu lexikálnej zásoby. $\mathrm{V}$ tejto koncepcii sa lexika považuje za súbor lexikálnych jednotiek navzájom spätých siet’ami rôznych vzt’ahov. J. Furdík vyčlenil celkovo 17 typov lexikálnej motivácie. Na Furdíkovu prácu nadviazal Martin Ološtiak (2011), ktorý túto teóriu značne rozšíril. Rovnako ako J. Furdík, aj M. Ološtiak vyčleňuje 17 typov lexikálnej motivácie, vrátane interlingválnej motivácie, ktorá je predmetom prvej časti našej štúdie. Interlingválnej motivácii sa venuje M. Ološtiak najmä v monografii Aspekty teórie lexikálnej motivácie (2011) a v d’alších čiastkových štúdiách (2012, 2015a, 2017b). Pred ním koncepciu interlingválnej motivácie načrtol J. Furdík (2008), ktorý však túto motiváciu nazval ako akceptačná motivácia (porov. Furdík 2008: 68-70; Ološtiak 2011: 195-228). Podl’a J. Furdíka aktívnu úlohu v procese preberania lexém z jedného jazyka do druhého hrá preberajúci jazyk. M. Ološtiak uvádza, že „termín akceptačná motivácia nezahŕňa všetky možné kontaktové prípady“ a prikláňa sa k termínu interlingválna motivácia (2011: 196).

Interlingválna motivácia, teda preberanie lexém z východiskového jazyka $\mathrm{L}_{1}$ do ciel’ového jazyka $\mathrm{L}_{2}$ je jedným z najproduktívnejších spôsobov obohacovania lexikálnej 
zásoby $\mathrm{v}$ jazyku $\mathrm{L}_{2}$. Rovnaká situácia je aj $\mathrm{v}$ odbornej jazykovednej terminológii. Jednotlivé termíny, prebraté najmä $\mathrm{z}$ latinčiny a gréčtiny, $\mathrm{v}$ mnohých prípadoch majú internacionálny charakter, napr. morféma (slov.) - morfem (pol.) - morpheme (angl.) das Morphem (nem.) - morphème (franc.); singulár (slov.) - singularis (pol'.) - singular (angl.) - der Singular (nem.) - singulier (franc.); infinitiv (slov.) - infinitivus (pol'.) infinitive (angl.) - der Infinitiv (nem.) - infinitif (franc.). Ciel'om internacionálnej terminologickej lexiky je ul'ahčit' profesijnú komunikáciu na medzinárodnej úrovni, dochádza tak $\mathrm{k}$ zharmonizovaniu terminologických sústav na formálnej i pojmovej úrovni. Podl'a niektorých autorov termíny prevzaté z klasických jazykov (latinčina, gréčtina) si zachovávajú status internacionalizmu dokonca aj vtedy, ak vystupujú len v jednom jazyku $\mathrm{L}_{2}$, a to vd'aka ich zrozumitel'nosti pre cudzojazyčné profesijné prostredie (porov. Lukszyn-Zmarzer 2006: 71-72). „Lingvistické internacionalizmy zohrávajú pozitívnu úlohu aj v procese učenia sa cudzích jazykov a vo všeobecnosti ul'ahčujú medzijazykové porozumenie,“ čo je aj dôvodom toho, prečo mnohí autori jazykovedných slovníkov a encyklopédií cielene používajú na pomenovanie lingvistických javov práve internacionálne termíny (Vojteková 2018: 22). Napr. autori Encyklopedie językoznawstwa ogólnego (Polański et al. 1999) uprednostňujú ako hlavné heslo prevzatý termín accusativus, pričom domáce pomenovanie tohto pádu biernik je v encyklopédii zaznamenané s odkazom na internacionálny termín (biernik zob. accusativus; podobne aj czynna strona zob. activum a i.).

V slovenskej a pol'skej jazykovednej terminológii sa možno stretnút' aj s ojedinelými prípadmi tzv. zdanlivej medzinárodnosti (Vojteková 2018: 25), kde sa na pomenovanie jedného denotátu používajú termíny prevzaté z rozličných jazykov, napr. slov. modus (lat.) - pol'. tryb (nem.). Podl’a Slovníka slovanské lingvistické terminologie možno považovat' slovenský termín modus za internacionálny, ked’že sa vyskytuje vo viacerých slovanských jazykoch (napr. čeština, slovinčina, macedónčina), naopak pol'ský termín tryb sa nevyskytuje v žiadnom zo zohl'adnených jazykov (porov. Jedlička et al. 1977: 384-385).

Interlingválne motivované (prevzaté) a interlingválne nemotivované (domáce) termíny môžu v oboch jazykoch navzájom vstupovat' aj do vzt’ahu synonymie (napr. slov. flexia / ohýbanie, interjekcie / citoslovcia, imperatív / rozkazovaci spôsob; pol'. positivus / stopień równy, interiekcja / wykrzyknik, dualis / liczba podwójna) alebo sa vyskytujú ako jediné pomenovanie termínu: prevzaté termíny (napr. slov. morféma, supletivizmus, nominativ; pol'. morfem, supletywizm, reflexiva tantum) a domáce termíny (napr. slov. slovné druhy, dvojtvar, vôlové citoslovcia; pol'. części mowy, bezokolicznik, liczebnik). Tejto problematike sme sa venovali v našom 
predchádzajúcom výskume (porov. Vincejová 2019), v ktorom sme predstavili synonymiu na osi domáci - prevzatý termín na medzijazykovej úrovni.

V d'alšej časti štúdie sa zameriame na jazykovednú terminológiu konkrétnej jazykovej roviny - morfologickej roviny. Pri uvádzaní výsledkov budeme vychádzat’ zo slovníka Slovensko-pol'sko-ruský slovník jazykovedných termínov II. Morfológia, ktorý sme podrobili detailnej analýze z hl’adiska interlingválnej motivácie. Ide o slovník, ktorý vychádza $z$ jestvujúceho a súčasného stavu jazykov a ich terminologických opisov, všetky termíny uvedené v tomto slovníku možno považovat' za prijaté, akceptované a používané v súčasnej slovenskej, pol'skej i ruskej jazykovede. V slovníku je dôsledne zachovaná synonymia na osi domáci - prevzatý termín, ked’že v rámci jedného hesla vystupujú synonymické termíny.

$\mathrm{Na}$ základe uskutočneného výskumu v Slovensko-pol'sko-ruskom slovníku jazykovedných termínov II. Morfológia, môžeme konštatovat', že v morfologickej rovine slovenského jazyka je výskyt prevzatých termínov nasledovný ${ }^{1}: \mathrm{v}$ latinčine má pôvod 87,5 \% termínov (napr. abtraktá, akuzatív, deklinácia, flexia, futúrum, gradácia, infinitív, infix, komparativ, kondicionál, konjugácia, modus, préteritum, reflexíva, singulár, supletivizmus, transgresív); v gréčtine 12,5\% (napr. alomorfémy, graméma, morfológia, morféma, paradigma, synkretizmus, onomatopoje) z celkového počtu prevzatých termínov. V rámci morfologickej roviny sa v slovenčine nevyskytujú lexémy iného cudzieho pôvodu ako latinského a gréckeho.

V pol'skej terminológii sa objavujú termíny ${ }^{2}$ pochádzajúce z latinčiny $74 \%$ (napr. apellativa, comparativus, deklinacja, imperfektywizacja, koniugacja, partykuła, pluralia tantum, supletywizm, walencja), z gréčtiny $22 \%$ (napr. morfem, morfologia, onomatopeje, synkretyzm), z iných jazykov 4 \% (z francúzštiny (apel), z nemčiny (tryb) $\mathrm{z}$ celkového počtu prevzatých termínov.

\section{Morfologické termíny $z$ aspektu abreviačnej motivácie}

Abreviácia si v poslednom období našla svoje významné uplatnenie nielen v spoločenskom živote, ktorý sa snaží o úspornú jazykovú komunikáciu (predovšetkým v písanej podobe), ale aj odborné terminologické sústavy si čoraz častejšie osvojujú

\footnotetext{
1 Pôvod slovenských termínov uvádzame na základe lexikografických publikácií: Slovník cudzích slov (akademický) (Petráčová-Kraus et al. 2006), Slovník súčasného slovenského jazyka. A-G (Buzássyová-Jarošová et al. 2006), Slovník súčasného slovenského jazyka. H-L (Jarošová-Buzássyová et al. 2011), Slovník súčasného slovenského jazyka. M-N (Jarošová et al. 2015).

2 Pôvod pol'ských termínov uvádzame na základe lexikografických publikácií: Słownik wyrazów obcych i zwrotów obcojęzycznych z almanachem (Kopaliński 2007), Uniwersalny słownik języka polskiego (Dubisz et al. 2003), Wielki słownik języka polskiego (Żmigrodzki et al., dostupné na internete).
} 
skracovanie. Potreba skracovania sa spája predovšetkým s rýchlym životným tempom posledných desat'ročí a snahou úsporne a vecne popísat' jednotlivé javy. So skratkami sa stretávame aj v odborných terminológiách mnohých vedných odborov, predovšetkým však v technických odboroch (napr. informatika, mechanika) a prírodných vedách (napr. matematika, fyzika, chémia). Skratky sa stali dôležitou súčastou aj mnohých lingvistických publikácií, prevažne lexikografického a encyklopedického charakteru a ,...bez abreviačného aparátu sa nezaobíde žiadne lexikografické dielo“ (Ološtiak 2011: 259). S abreviáciou sa v pomerne vel'kom počte stretávame aj $\mathrm{v}$ rôznych odborných jazykovedne zameraných monografiách a vedeckých prácach, kde sa zvyknú skracovat' najmä kl'účové a často sa opakujúce lingvistické termíny.

Teoretickým východiskom našej štúdie je koncepcia lexikálnej motivácie, ktorú načrtol Juraj Furdík (2008), a ktorú vo viacerých prácach komplexne rozvinul Martin Ološtiak (2011, 2015a, 2015b, 2017). Konkrétne abreviačnej motivácii (AM) sa osobitne venovala Miroslava Gavurová (2013), ktorá sa opierala o Furdíkovu a Ološtiakovu teóriu lexikálnej motivácie.

Predmetom predkladanej kapitoly sú abreviačne motivované lexémy, teda skratky, v slovenskej a pol'skej lingvistickej terminológii. Prinesieme prehl'ad jednotlivých skratiek ako abreviačne motivovaných lexém, ktoré budeme analyzovat' z hladiska ich výskytu, formy a zapojenosti do paradigmatických vztahov, pričom upozorníme na zhody a rozdiely $\mathrm{v}$ tejto odbornej lexike.

Podla J. Furdíka pri abreviačnej motivácii ,ide o kontakt prirodzeného jazyka s jeho graficky špecifikovanou podobou“ (Furdík 2008: 68). Samotné skracovanie je pritom podl'a neho „prechodom do iného subkódu“ (Furdík, 2008: 68). Skratky sa považujú za plnohodnotné lexémy a samotné ,skracovanie je dôsledkom snahy o jazykovú ekonómiu“, ktorého hlavným účelom je „aby sme na čo najmenšej ploche vyjadrili čo najviac sémantických príznakov" (Ološtiak 2011:240). Nie je ničím výnimočným, že o takúto jazykovú úsporu (prevažne v písanej podobe) majú záujem aj autori rôznych typov slovníkov a encyklopédií, jazykových príručiek i lingvisticky zameraných monografií, ktorí sa v rozsiahlych publikáciách snažia o ul'ahčenie, zefektívnenie a urýchlenie jazykovej komunikácie medzi expedientom a percipientom. Najčastejšie sa prejavuje potreba skracovat' viacslovné pomenovania ako formálne nákladnejšie jednotky a často sa opakujúce lingvistické termíny.

Pri procese abreviácie vzniká medzi abreviačným motivantom (neskratkou) a abreviačným motivátom (skratkou) abreviačný motivačný vzt’ah. Abreviačným motivantom je každá lexéma, syntagma alebo vol'né spojenie lexém, ktoré sú pri procese abreviačnej motivácie východiskom pre utvorenie abreviačného motivátu, teda sktratky. 
Výsledkom abreviačného procesu je abreviačný motivát, ktorým je každá abreviačne motivovaná lexéma (Gavurová 2013: 15-17). Pri samotnej abreviácii je však dôležité, aby skratka nestratila zrozumitel'nost' a komunikačnú efektívnost' (Furdík, 2008: 71).

Abreviačne motivované lexémy ul’ahčujú jazykovú komunikáciu medzi expedientom a percipientom, kde najmä pre expedienta ide o jednoduchšie a ekonomickejšie opísanie javu, avšak pre percipienta môže íst' o neporozumenie skratky, čím sa komunikačný akt stáva neprehl'adným a t’ažko dekódujúcim, preto „expedient komunikátu musí zhodnotit' komunikačný štatút skratky, jej frekventovanost', schopnost' percipienta dekódovat' skratku, priradit' jej adekvátny abreviačný motivant a sémantický obsah“ (Gavurová 2013: 25). Aj z tohto dôvodu v každom jazykovednom slovníku (výkladovom i prekladovom), encyklopédii či monografii nájdeme zoznam použitých skratiek, ktoré používatel'ovi danej publikácie ozrejmujú priradenie jednotlivých abreviačných motivátov (skratiek) k ich abreviačným motivantom (neskratkám). Platí pritom aj skutočnost', že „poznanie sémantiky abreviatúry je podmienené poznaním sémantiky východiskového pomenovania“ (Furdík 2008: 71).

\subsection{Abreviácia v slovenskej a pol'skej lingvistickej terminológii}

S abreviačnou motiváciou sa stretávame aj v odbornej terminológii, „tým sa naplńa predpoklad, že AM je dôležitým identifikačným a spoluorganizačným faktorom vplývajúcim na fungovanie odbornej terminológie“ (Ološtiak 2011: 259). Tak ako v lexikálnej zásobe ako celku, tak aj v odbornej terminológii sú skratky „výsledkom úsilia o úsporné, ekonomické zachytenie lexém alebo časti jazykového prejavu“ (Furdík 2008: 70).

V lingvistickej terminológii sa so skratkami primárne stretávame $\mathrm{v}$ jazykových slovníkoch (výkladových i prekladových) ako aj v odborných lingvistických slovníkoch a encyklopédiách. V našej analýze sme sa zamerali na nasledovné jestvujúce slovenské výkladové slovníky, jazykovedné príručky a odborné lingvistické slovníky a encyklopédie obsahujúce skratky lingvistických termínov: Krátky slovník slovenského jazyka (Kačala-Pisárčiková-Považaj et al. 2003), Slovník súčasného slovenského jazyka. A-G (Buzássyová-Jarošová et al. 2006), Slovník súčasného slovenského jazyka. H-L (Jarošová-Buzássyová et al. 2011), Slovník súčasného slovenského jazyka. M-N (Jarošová et al. 2015), Slovník slovenského jazyka I-VI (Peciar et al. 1959-1968), Slovník cudzích slov (akademický) (Petráčková-Kraus et al. 2005), Synonymický slovník slovenčiny (Písárčiková et al. 2004), Pravidlá slovenského pravopisu (Považaj et al. 2013), Encyklopédia jazykovedy (Mistrík et al. 1993). 
Z jestvujúcich pol'ských lingvistických slovníkov a odborných jazykovedných slovníkov a encyklopédií sme analyzovali: Inny słownik języka polskiego PWN. A-Ó, P-Ż (Bańko et al. 2000), Uniwersalny słownik języka polskigo. A-J, K-O, P-Ś, T-Ż (Dubisz et al. 2006), Słownik poprawnej polszczyzny (Szober 1968), Słownik języka polskiego PWN. A-K (Szymczak et al. 1978), Slownik języka polskiego PWN. L-P (Szymczak et al. 1982), Słownik języka polskiego PWN. R-Ż (Szymczak et al. 1981), Slownik języka polskiego PWN. A-K, L-P, R-Z (Szymczak et al. 2002), Encyklopedia językoznawstwa ogólnego (Polański et al. 2003), Encyklopedia języka polskiego (Urbańczyk-Kucała et al. 1999) a prekladový slovník Słownik slowacko-polski A-Ô, P-Ž (Jurczak-Trojan-Mieczkowska-Orwińska-Papierz 2010). Abreviačne motivované termíny $\mathrm{v}$ týchto publikácia sme podrobili analýze z hl'adiska typu jednotlivých skratiek, ich výskytu, formy a zapojenosti do paradigmatických vzt’ahov.

Z uskutočneného výskumu skratiek $\mathrm{v}$ uvedených publikáciách vyplýva, že $\mathrm{v}$ lingvistickej terminológii sa stretávame predovšetkým s ustálenými grafickými typmi skratiek $^{3}$. V slovenskej jazykovednej terminológii sa objavujú najmä jednoduché iniciálové skratky, napr. m. (podstatné meno mužského rodu), ž. (podstatné meno ženského rodu), $n$. (podstatné meno stredného rodu); jednoduché lineárne skratky, napr. neurč. (neurčitok), prísl. (príslovka), spoj. (spojka), zám. (zámeno), príč. (príčastie), čast. (častica); zriedkavejšie sa objavujú zložené iniciálové skratky, napr. j. č. (jednotné čislo), skeletové skratky, napr. sg. (singulár) a kombinované skratky, napr. min. $\check{c}$. (minulý čas), mn. č. (množné číslo).

Podobná situácia ako v slovenskej jazykovednej terminológii je aj v pol'skej jazykovede. Aj tu sa možno stretnút' prevažne s ustálenými grafickými typmi skratiek ${ }^{4}$. Medzi najčastejšie sa vyskytujúce patria jednoduché iniciálové skratky, napr. $c z$. (czasownik), r. (rodzaj), f. (femininum); jednoduché lineárne skratky, napr. mian. (mianownik), miejsc. (miejscownik), imiest. (imiestów), przym. (przymiotnik), rzecz. (rzeczownik), bezok. (bezokolicznik), part. (partykuła) a kombinované skratky, napr. l. mn. (liczba mnoga), l. podw. (liczba podwójna), rodz. m. (rodzaj męski), rodz. n. (rodzaj nijaki), cz. przysz. (czas przyszty). V pol'skej lingvistickej terminológii sa v menšej miere možno stretnút' aj so zloženými iniciálovými skratkami, napr. $l m$. / lm (liczba mnoga), lp. I lp (liczba pojedyncza), zloženými lineárnymi skratkami, napr. imwsp (imiestów przystówkowy wspótczesny) a skeletovými skratkami, napr. Msc. (miejscownik), ndk. (niedokonany), ndm (nieodmienny).

\footnotetext{
${ }^{3} \mathrm{~V}$ našej analýze sme sa orientovali na typológiu skratiek v publikácii Skratka ako lexéma (abreviačná motivácia v lexike) (Gavurová 2013: 25-27).

${ }^{4} \mathrm{Na}$ analýzu a typológiu pol'ských abreviatúr sme použili slovenské terminologické pomenovania skratiek (Gavurová 2013: 25-27).
} 
Typickým znakom grafických skratiek je, že sa pri abreviácii ponecháva začiatok slova ako informačne relevantnejšia čast' a vypúšt’a sa koniec slova, napr. slov. predl. (predložka); pol'. bezok. (bezokolicznik). Pravidlo, že významnejšími nositel’mi informácie sú konsonanty, potvrdzujú skeletové a kombinované značky, napr. slov. sg. (singulár); pol'. Msc. (miejscownik). Pre pravopis slovenských grafických značiek je klúčovým pravidlom písanie bodky za grafickou skratkou, napr. cit. (citoslovce). V pol'skom pravopise je pravidlo písania grafických skratiek sčasti odlišné. Hoci sa za grafickými skratkami píše bodka, v prípadoch, kedy skratka obsahuje aj poslednú grafému abreviačného motivantu, sa bodka nepíše. Medzi abreviačnými motivátmi pol'ských lingvistických termínov sa však objavujú prípady porušenia tejto normy, napr. $d k$ (dokonany), ger (gerundium), Im (liczba mnoga), $n$ (rodzaj nikaki), os (osoba) a i.

Graficko-fónické skratky lingvistických termínov sa v slovenských a pol’ských (výkladových ako aj prekladových) slovníkoch a príručkách vyskytujú v minimálnej miere, napr. slov. I (inštrumentál), VM (vlastné meno), pol'. CZ (czasownik), LM (liczba mnoga). Tento typ skratiek je ovel’a produktívnejší v monografiách a vedeckých prácach lingvistického charakteru.

\subsection{Abreviačná synonymia, paronymia a homonymia}

Skratka „sa môže vyznačovat' inou zapojenost’ou do lexikálnoparadigmatických vzt'ahov" (paronymia, polysémia, homonymia, slovotvorné vzt'ahy) ako neskratka (Ološtiak 2011: 233). Ide o spoluprácu abreviačnej motivácie a paradigmatickej motivácie. Pri terminologickej lexike možno hovorit' o kooperácii troch motivácii terminologickej, abreviačnej a paradigmatickej, ktoré sa prejavujú v začleňovaní skratiek odborných termínov do rozličných lexikálnych paradigiem. V prípade jazykovednej terminológie ide o realizáciu paradigmatických vzt’ahov na úrovni skratka - neskratka, kde ide najmä o homonymickú, paronymickú, synonymickú paradigmu. M. Ološtiak hovorí o abreviačnej homonymii, paronymii a synonymii ${ }^{5}$ (2011: 246249).

\subsubsection{Abreviačná synonymia}

Mnohé skratky slovenských a pol'ských lingvistických termínov sú ustálené, čo dokazuje aj ich opakujúci sa výskyt v rôznych typoch slovníkov, encyklopédií a jazykovedných príručiek. Medzi takéto ustálené skratky patria napr. slov. bud. (budúci

\footnotetext{
${ }^{5}$ M. Ološtiak hovorí aj o abreviačnej antonymii, hyperonymii, hyponymii, meronymii a abreviačných lexikálnoonomaziologických paradigmách, ale ked’že $\mathrm{v}$ jazykovednej terminológii ide o ojedinelé javy, $\mathrm{v}$ našej práci im nebudeme venovat' pozornost'.
} 
čas), čast. (častica), m. (podstatné meno mužského rodu), os. (osoba); pol. bezok. (bezokolicznik), imiest. (imiestów), part. (partykuła), przym. (przymiotnik). Početné množstvo lingvistických termínov sa však skracuje do rôznych podôb, napr. slov. akuzatív - A / akuz. / 4. p., citoslovce - cit. / citosl., jednotné čislo - j. č. / jedn. / j., minulý čas - min. / min. č.; pol'. biernik - B / B. / biern., liczba mnoga - lm / lm. / l. mn., miejscownik-Ms. / Msc. / miejsc., rodzaj żeński $-\dot{z}$ / ż. / rż. / rodz. ż. Pri takýchto obmenách skratiek však podl'a M. Ološtiaka nejde o synonymiu, ale považuje ich za varianty (2011: 248). V lingvistickej terminológii sa však možno stretnút' aj $\mathrm{s}$ abreviačnou synonymiou, ktorú zapríčiňujú skratky interlingválne motivovaných a interlingválne nemotivovaných termínov, ktoré sú v synonymickom vzt’ahu, napr. slov. neurč. (neučitok) - inf. (infinitív), j. č. / jedn. / j. (jednotné číslo) - sg. / sing. (singulár), mn. č. / mn. (množné čislo) - pl. (plurál), str. / s. (podstatné meno stredného rodu) - n. / neutr. (neutrum), príd. (prídavné meno) - adj. (adjektívum); pol'. l. poj. I lp / lp. (liczba pojedyncza) - sg. / sing. (singularis), cz. przysz. / przysz. (czas przyszły) fut. (futurum), imiest. (imiesłów) - part. (participium), rodz. m. / rm. / m. (rodzaj męski) - m. I masc. I masc (masculinum), tr. rozk. I rozk. (tryb rozkazujacy) - Imp. (imperativus).

\subsubsection{Abreviačná paronymia}

Medzi skratkami slovenských a pol'ských lingvistických termínov možno nájst' aj abreviačné paronymá. Ide o formálne podobné skratky, ktorých abreviačné motivanty však nemusia byt' paronymami, napr. slov. min. č. (minulý čas), mn. č. (množné číslo); os. (osoba), osob. (osobné zámeno), morfol. (morfológia), morfonol. (morfonológia); pol'. $m$ / m. (rodzaj męski), M / M. (mianownik), Ms. / Msc. (miejscownik); $N$. (narzędnik), n. (rodzaj nijaki); cz. (czas), czas. (czasownik). M. Ološtiak pri skratkách uvažuje o špecifickom prejave poronymie, tzv. ortografickej paronymii prejavujúcej sa viacerými spôsobmi, ktoré M. Gavurová doplnila o d’alšie prípady (porov. Ološtiak 2011: 247-248; Gavurová 2013: 72-73). Pri lingvistickej terminológii sa objavujú najmä: a) odlišnosti v písaní majuskúl a minuskúl, napr. slov. $N$ (nominatív), $n$ (neutrum); pol'. $M / M$. (mianownik), $m / m$. (rodzaj męski); b) odlišnost' v nealfabetickom znaku, napr. slov. $\langle>:\langle g\rangle$ (z gréčtiny), G (genitív); ( ): prísl. (prislovka), (prisl.) (prislovie). Pri analýze uvedených lexikografických zdrojom sme navyše zaznamenali aj odlišnost' $\mathrm{v}$ dolnom indexe, napr. slov. $L_{1}$ (východiskový / zdrojový jazyk), $L_{2}$ (preberajúci / cielový jazyk); pol'. $V_{\text {intr }}$ (czasownik nieprzechodni), $V_{t r}$ (czasownik przechodni) a odlišnost' v numerickom znaku, napr. slov. 1. p. (1. pád I nominatív), 2. p. (2. pád / genitív) a pod., pol'. os1 (osoba pierwsza), os2 (osoba druga), os3 (osoba trzecia). 


\subsubsection{Abreviačná homonymia}

Pri abreviačnej homonymia ide o formálne identické skratky, ktoré však majú rozdielne abreviačné motivanty (Ološtiak 2011: 246). V slovenskej a pol'skej lingvistickej terminológii ide o ojedinelý jav, avšak možno nájst' prípady, kedy dochádza k abreviačnej homonymii medzi jednotlivými abreviačne motivovanými termínmi, napr. slov. neurč. - 1. neučité (zámeno), neurčitá (čislovka); 2. neurčitok; pol'. jęz. - 1 . język; 2. językoznawstwo, $L$ - 1. w fonetyce i fonologii - spółgłoska plynna; 2. w językoznawstwie algebraicznym - język (łac. lingua); 3. zmienna lokatywa. O niečo častejšie sú príklady, kedy pri homonymných skratkách iba jeden $\mathrm{z}$ abreviačných motivantov je lingvistický termín, napr. slov. str. - 1. stredný rod; 2. strana; s. -1 . podstatné meno stredného rodu; 2. strana; VM-1. vlastné meno; 2. Velká Morava; MŠ - 1. morfematická štruktúra; 2. materská škola; pol'. cz. - 1. czas; 2. część; lp. - 1. liczba pojedyncza; 2. liczba porzadkowa; $n$. - 1. rodzaj nijaki; 2 . nad; gen. - 1. genetivus; 2. generał; rż. - rodzaj żeński; 2. rok życia.

\subsection{NeúpIné skratky}

Väčšina skratiek utvorených z viacslovných pomenovaní si zachováva všetky relevantné sémantické príznaky abreviačného motivantu zohl'adnením všetkých autosémantických lexém prítomných v motivante, teda sú skracované všetky komponenty viacslovného pomenovania, napr. slov. min. ̌̌. (minulý čas), j. č. (jednotné čislo), podst. m. (podstatné meno); pol'. lp. I lp (liczba pojedyncza), cz. ter. (czas teraźniejszy), tr. ozn. (tryb oznajmujacy). Tak ako medzi skratkami v bežnej komunikácii, tak aj v lingvistickej terminológii sa možno stretnút' so skratkami, v ktorých nemajú zastúpenie všetky komponenty viacslovného pomenovania, napr. slov. dok. (sloveso dokonavého vidu), hromad. (hromadné podstatné meno), pomn. (pomnožné podstatné meno), m. (mužský rod), bud. (budúci čas), podst. (podstatné meno), podm. (podmieňovací spôsob); pol'. m. / m (rodzaj męski), ż. / $\dot{z}$ (rodzaj żeński), rozk. (tryb rozkazujacy), OZN (tryb oznajmujacy), przesz. (czas przeszyy), TER (czas teraźniejszy), imb (imiestów przymiotnikowy bierny), imuprz (imiestów przysłówkowy uprzedni). Takéto skratky označujeme termínom neúplné skratky. Ide o snahu jazykovej ekonómie vynechaním sémanticky „menej dôležitých“ komponentov viacslovného pomenovania. M Gavurová hovorí o vynechávaní synsémantických komponentov, v odbornej lingvistickej terminológii však dochádza aj $\mathrm{k}$ vynechaniu autosémantických komponentov (2013: 57-60). Zachovávajú sa však vždy komponenty viacslovného pomenovania, ktoré obsahujú relevantnejšiu informáciu a vypúštajú sa tie, ktoré nesú sémanticky menej dôležitú informáciu. 


\section{Záver}

V predkladanom príspevku sme predstavili slovenské a pol'ské lingvistické termíny z aspektu dvoch vybraných typov lexikálnej motivácie - interlingválnej motivácie a abreviačnej motivácie, na základe ktorých sme predstavili početné zhody a podobnosti, ale aj rozdiely $\mathrm{v}$ tejto špecifickej časti lexiky. Zhody sú výrazným ukazovatel’om genetickej príbuznosti a areálovej blízkosti slovenčiny a pol'štiny. Prícinami rozdielov v lexike týchto dvoch západoslovanských jazykov sú samostatné vývinové procesy, ako aj odlišné kultúrne a mentálne vlastnosti ich nositelov, geomorfologické vlastnosti obidvoch krajín, vnútropolitické rozdiely a pod.

Slovenskú a pol'skú lingvistickú terminológiu tvoria termíny domáceho pôvodu (interlingválne nemotivované) i cudzieho pôvodu (intelingválne motivované). Z uskutočneného výskumu jazykovednej terminológie vyplýva, že slovenská a pol'ská jazykovedná terminológia je vo výraznej miere latinského a gréckeho pôvodu. Vel'ká skupina termínov cudzieho pôvodu bola prevzatá aj do iných jazykov, vd’aka čomu nadobúda internacionálny charakter. Jednotlivé lexikografické a encyklopedické zdroje zhŕňajúce lingvistickú terminológiu pri synonymii domácich - prevzatých termínov zohl'adňujú jeden alebo druhy typ v rozličnej miere. Autori slovenských i pol'ských publikácií sa často prikláňajú len k jednému pomenovaniu - domácemu alebo prevzatému $\mathrm{v}$ závislosti od percipienta, ktorému je publikácia primárne určená alebo v závislosti od toho, či ide o populárno-náučné alebo striktné vedecké spracovanie.

V slovenskej a pol'skej lingvistickej terminológii sa objavujú skratky odborných termínov, ktoré sa stali dôležitou súčastou mnohých publikácií, prevažne lexikografického charakteru, kde sa zvyknú skracovat' najmä kl'účové a často sa opakujúce lingvistické termíny. Skratky jazykovedných termínov slúžia na ul'ahčenie, zefektívnenie a urýchlenie jazykovej komunikácie medzi expedientom a percipientom, kde najmä pre expedienta ide o jednoduchšie a ekonomickejšie opísanie javu, avšak pre percipienta môže íst' o neporozumenie skratky, čím sa komunikačný akt stáva neprehl'adným a t’ažko dekódujúcim, preto $\mathrm{v}$ každom slovníku (výkladovom i prekladovom), encyklopédii, jazykovej príručke či monografii možno nájst' zoznam použitých skratiek, ktoré používatel'ovi danej publikácie ozrejmujú priradenie jednotlivých abreviačných motivátov $\mathrm{k}$ ich abreviačným motivantom.

\section{Summary}

The paper describes and compares Slovak and Polish linguistic terms as terminologically motivated units from the perspective of selected lexical motivation types (interlingual and abbreviation). The paper is based on the theory of lexical 
motivation, the primary typology of lexical motivation and notional-terminological specification of particular motivation types by J. Furdík (2008) as well as on various publications by M. Ološtiak who has significantly developed the theory of lexical motivation.

\section{Literatúra}

Bańko, M. (ed.) Inny słownik języka polskiego PWN. Warszawa: Wydawnictwo Naukowe PWN, 2000.

Buzássyová, K., Jarošová, A. (eds.) Slovník súčasného slovenského jazyka. A-G. Bratislava: Veda, 2006.

Dubisz, S. (ed.) Uniwersalny stownik języka polskiego. Warszawa: Wydawnictwo Naukowe PWN, 2003.

Furdík, J. Teória motivácie v lexikálnej zásobe. Košice: Vydavatel'stvo LG, 2008.

Gavurová, M. Skratka ako lexéma (abreviačná motivácia v lexike). Prešov: Filozofická fakulta Prešovskej univerzity v Prešove, 2013.

Jarošová, A, Buzássyová, K. (eds.) Slovnik súčasného slovenského jazyka. $H-L$. Bratislava: Veda, 2011.

Jarošová, A. (ed.) Slovník súčasného slovenského jazyka. M-N. Bratislava: Veda, 2015.

Jedlička, A. (ed.) Slovnik slovanské lingvistické terminologie 1. Praha: Academia, 1977.

Jurczak-Trojan, Z., H. Mieczkowska, E. Orwińska, Papierz, M. Stownik stowackopolski. Kraków: Universitas, 2010.

Kačala, J., Pisárčiková, M., Považaj, M. (eds.). Krátky slovník slovenského jazyka. Bratislava: Veda, 2003.

Kopaliński, W. Stownik wyrazów obcych i zwrotów obcojęzycznych z almanachem. Warszawa: Oficyna Wydawnicza RYTM, 2007.

Lukszyn, J., Zmarzer, A. Teoretyczne podstawy terminologii. Warszawa: Uniwersytet Warszawski, 2006.

Mistrík, J. (ed.) Encyklopédia jazykovedy. Bratislava: Vydavatel'stvo Obzor, 1993.

Ološtiak, M. Aspekty teórie lexikálnej motivácie. Prešov: Filozofická fakulta Prešovskej univerzity v Prešove, 2011. 
Ološtiak, M. Poznámky ku koncepcii interlingválnej demotivácie. In: Buhunická, A. (ed.) Jazykoveda v pohybe. Bratislava: Univerzita Komenského, 2012, s. 148157.

Ološtiak, M. (ed.) Kvalitatívne a kvantitatívne aspekty tvorenia slov v slovenčine. Prešov: Filozofická fakulta Prešovskej univerzity v Prešove, 2015a.

Ološtiak, M. O terminologickej motivácii v lexike. In: Mislovičová, S. (ed.) Jazyková kultúra a terminológia: zborník štúdií venovaný Matejovi Považajovi. Bratislava: Veda, 2015b, s. 56-84.

Ološtiak, M. Lexikálna paradigmatika, sémantika a kombinatorika. Prešov: Prešovská univerzita v Prešove, 2017a.

Ološtiak, M. Slovotvorba, slovnodruhové prechody, preberanie a skracovanie lexém. Prešov: Prešovská univerzita v Prešove, $2017 \mathrm{~b}$.

Peciar, Š. (ed.) Slovník slovenského jazyka I-VI. Bratislava: Vydavatel'stvo SAV, 1959-1968.

Petráčková, V, Kraus, J. (eds.) Slovník cudzích slov (akademický). Bratislava: Slovenské pedagogické nakladatel'stvo - Mladé letá, 2005.

Pisárčiková, M. (ed.) Synonymický slovník slovenčiny. Bratislava: Veda, 2004.

Polański, K. (ed.) Encyklopedia językoznawstwa ogólnego. Wrocław: Ossolineum, 1999.

Považaj, M. (ed.) Pravidlá slovenského pravopisu. Bratislava: Veda, 2013.

Szober, S. Słownik poprawnej polszczyzny. Warszawa: Państwowy Instytut Wydawniczy, 1968.

Szymczak, M. (ed.) Stownik języka polskiego PWN. A-K. Warszawa: Państwowe Wydawnictwo Naukowe, 1978.

Szymczak, M (ed.) Słownik języka polskiego PWN. A-K. Warszawa: Państwowe Wydawnictwo Naukowe, 2002.

Urbańczyk, S., Kucała, M. (eds.) Encyklopedia języka polskiego. Wrocław: Ossolineum, 1999.

Vincejová, D. Slovenská a pol’ská lingvistická terminológia. In: Mikulášková, G. (ed.) 15. študentská vedecká a umelecká konferencia. Zborník príspevkov. Prešov: Filozofická fakulta Prešovskej univerzity v Prešove, 2019, s. 191-197. 
Vincejová, D. Slovenské a pol'ské lingvistické termíny z aspektu abreviačnej motivácie. In: Pachomovová, S. (ed.) Studia slovakistica 20. Užhorod: Vydavnyctvo Oleksandry Harkuši, 2020a (v tlači).

Vincejová, D. Slovenské a pol'ské lingvistické termíny z aspektu interlingválnej motivácie. In: Blaho, M. (ed.) 16. študentská vedecká a umelecká konferencia. Zbornik príspevkov. Prešov: Filozofická fakulta Prešovskej univerzity v Prešove, $2020 \mathrm{~b}$ (v tlači).

Vojteková, M. Slovenské a pol'ské jazykovedné termíny z aspektu vybraných typov lexikálnej motivácie. In: Vojteková, M. (ed.) Jazykovedná terminológia $v$ slovanskom kontexte. Prešov: Filozofická fakulta Prešovskej univerzity v Prešove, 2018, s. 7-37.

Vojteková, M. (ed.) Slovensko-pol'sko-ruský slovník jazykovedných termínov II. Morfológia. Prešov: Filozofická fakulta Prešovskej univerzity v Prešove, 2019.

Żmigrodzki, P. (ed.) Wielki słownik języka polskiego. Dostupné z: http://www.wsjp.pl/ (2021-04-15). 